\title{
The Legal Operation of Liens: Theory and Practice
}

M Wiese*

\section{P.E.R}

Pioneer in peer-reviewed, open access online law publications

Author

Mitzi Wiese

Affiliation

North-West University

South Africa

Email Mitzi.Wiese@nwu.ac.za

Date Submission

31 July 2020

Date Revised

3 February 2020

Date Accepted

3 February 2020

Date published

19 February 2021

Editor Prof C Rautenbach

How to cite this article

Wiese $M$ "The Legal Operation of Liens: Theory and Practice" PER / PELJ 2021(24) - DOI

http://dx.doi.org/10.17159/1727-

$3781 / 2021 / v 24 i 0 a 8721$

\section{Copyright}

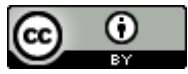

DOI

http://dx.doi.org/10.17159/17273781/2021/v24i0a8721

\begin{abstract}
The legal operation of liens has been the source of academic debates for many years. Liens are traditionally classified as enrichment liens and debtor-and-creditor liens (contractual liens). In the instance of an enrichment lien the creditor (lienholder) has a contract with a non-owner and not with the owner (debtor) himself. Consequently, the creditor can vest a lien against the owner of the thing only on the grounds of unjustified enrichment. Enrichment liens are classified as real rights. In the instance of a debtor-and-creditor lien (contractual lien) the creditor (lienholder) has a contract with the owner of the thing and the contract is the basis for the liability of the owner (debtor) towards the creditor. Debtor-and-creditor liens are generally classified as personal rights. This classification causes confusion regarding the legal operation on the one hand of an enrichment lien as a real right and on the other hand of a debtorand-creditor lien (contractual lien) as a personal right. This paper proposes that the origin of the legal claim for which the lien serves as security (unjustified enrichment or contractual) merely determines the debt (expenses) for which a lienholder can vest his lien and does not determine the classification of a lien as either a real right or a personal right. A lien can be described as a defence against the owner's rei vindicatio and is, in principle, enforceable only against the owner of the thing (security object). A lien can, however, also be enforced against parties other than the owner, including the creditors (who, for example, want to attach the thing subject to the lien) of the owner (debtor) and other real claimants. The enforcement of a lien against these parties is referred to as the real operation (third-party action) of a lien. This paper analyses the legal operation of a lien with specific reference to the debt (expenses incurred) secured by the lien, the vesting (existence) of a lien, the real operation (thirdparty action) of a lien and the preferential position of a lienholder in the case of the debtor' insolvency.
\end{abstract}

\section{Keywords}

Lien (right of retention); capacity to withhold; real security right; real right; personal right; defence against rei vindicatio; exceptio non adimpleti contractus; insolvency; real operation. 


\section{Introduction}

Liens (rights of retention) are presently classified as enrichment liens, that are regarded as real rights, and contractual liens or debtor-and-creditor liens, ${ }^{1}$ that are mostly regarded as personal rights. ${ }^{2}$ United Building Society $v$ Smookler's Trustees and Golombick's Trustee,${ }^{3}$ the first judgment which distinguished between enrichment liens and debtor-and-creditor liens, described enrichment liens as real rights and directly scrutinised the operation of various liens. Although this judgment had a great deal of influence on later judgments, it is a local division judgment of which I remain highly critical. According to some authors, ${ }^{4}$ a lien is not a subjective right (either a real right or a personal right), but a legally recognised retention capacity to which the lienholder has an extrajudicial claim and is a defence against the owner's rei vindicatio (or the claim to the thing of another real claimant). Regarding the classification of liens, I shall show that this is indicative only of the origin of a lien and has no effect on its third-party operation.

Mitzi Wiese. LLB LLM LLD. Associate Professor, Faculty of Law, North-West University (Potchefstroom Campus), South Africa. E-mail: mitzi.wiese@nwu.ac.za. ORCID 0000-0001-5984-2710. A version of this paper was presented at the Annual Property Law Teachers Conference in November 2019 at the University of Pretoria. Thank you to the participants for their valuable feedback on this topic. This work is based on research supported in part by the National Research Foundation of South Africa.

1 In the case of a "contractual lien" or "debtor-and-creditor lien", I prefer the term "contractual lien" to the term "debtor-and-creditor lien" because the latter term gives no indication of the source of the personal right which the lien protects. Additionally, in both situations (enrichment liens and contractual/debtor-and-creditor liens) there are debtors and creditors, though the source of their obligations differs.

$2 \quad$ Scott and Scott Mortgage and Pledge 85-93; Van der Merwe Sakereg 711-724; Scott "Lien" paras 49-50, 60 and 70, 418; Scott "Law of Real and Personal Security" 273274; Mostert and Pope (Beginsels van die Sakereg 365-367; Brits Real Security Law 487; and Muller et al Law of Property 487-495.

$3 \quad$ United Building Society $v$ Smookler's Trustees and Golombick's Trustee 1906 TS 623 was the first decision to deal with various aspects of liens. This decision is open to criticism in various respects. This decision was frequently cited as authority in subsequent decisions (such as Brooklyn House Furnishers (Pty) Ltd v Knoetze and Sons 19703 SA 264 (A) 271; D Glaser and Sons (Pty) Ltd v The Master 19794 SA 780 (K) 787; Syfrets Participation Bond Managers Ltd v Estate and Co-op Wine Distributors (Pty) Ltd 19891 SA 106 (W) 110C; Goudini Chrome (Pty) Ltd v MCC Contracts (Pty) Ltd 19931 SA 77 (A)) and consequently some of the inaccuracies came to be accepted as the correct position regarding liens. See Wiese $2017 \mathrm{LitNet}$ Regte 304-321.

$4 \quad$ Brits Real Security Law 487-488; Sonnekus and Neels Sakereg Vonnisbundel 771; Sonnekus Ongegronde Verryking 219-220, Sonnekus 1991 TSAR 462-482; Muller et al Law of Property 488; and Wiese 2017 LitNet Regte 304-321. 
There is some uncertainty regarding the so-called "third-party" or "real" operation of liens. The question of the operation of liens against third parties has contributed to some extent to the classification of liens as real rights (enrichment liens) and personal rights (debtor-and-creditor liens). This classification probably became necessary because the question arose as to when and in what circumstances the lien is enforceable against the owner. The view espoused in certain judgments, ${ }^{5}$ namely that an enrichment lien is a real right, is related to the fact that an enrichment lien can be enforced against an owner while the creditor actually had a contract with a third party in terms of which the creditor invested money or labour in the owner's thing. The uncertainty regarding the so-called "real operation" or "third-party operation" of liens has, in my opinion, arisen because of a failure to distinguish between the existence of a lien and its real operation.

On the basis of various judgments and, where applicable, the works of various authors, I shall proceed to analyse the legal operation of liens. The following aspects are analysed: the debts (expenses incurred) for which a lien can vest; the existence of a lien the operation of a lien against third parties; and the preferential position of a lienholder vis-à-vis other creditors.

\section{Debt (expenses incurred) secured by a lien}

The expenses for which a lienholder can vest his lien are determined by the origin of the legal claim for which the lien serves as security. In the case of enrichment liens the lien can vest only for useful and necessary expenses. The extent of the lien is determined by enrichment. Contractual liens serve to secure the contractual legal claim and the amount is specified in the contract. This amount is therefore not restricted to useful and necessary expenses, as in the case of enrichment liens. Some authors and decisions demonstrate that contractual liens apply to luxury expenditure. On the surface it appears that a contractual lien can vest only in respect of luxury expenses. ${ }^{6}$ In my opinion this is not the case. Where the contract has been concluded with the owner, the contractual lien vests for all expenses which

5

See for example: United Building Society v Smookler's Trustees and Golombick's Trustee 1906 TS 623; Kommissaris van Binnelandse Inkomste v Anglo American (OFS) Housing Co Ltd 19603 SA 642 (A); Brooklyn House Furnishers (Pty) Ltd v Knoetze and Sons 19703 SA 264 (A); Lubbe v Volkskas Bpk 19923 SA 868 (A); and Goudini Chrome (Pty) Ltd v MCC Contracts (Pty) Ltd 19931 SA 77 (A).

$6 \quad$ This view may possibly have originated from United Building Society $v$ Smookler's Trustees and Golombick's Trustee 1906 TS 623, 628-629. In this decision Bristowe $\mathrm{J}$ contended that a creditor can vest two liens: one for the enrichment amount and one for luxury expenditure. Later on in the judgment the judge rightly indicated that a contractual lien vests for the contract price. 
have been agreed upon, in other words to ensure the contract price. The reference to a contractual lien for luxury expenses merely illustrates that such expenses can be secured by a contractual lien only if the contract has been concluded with the owner, and never through an enrichment lien. Next I shall refer briefly to case law on the recovery of various expenses.

In United Building Society v Smookler's Trustees and Golombick's Trustee ${ }^{7}$ the builder (Golombick) had a lien against the owner of the land (Smookler) in terms of an agreement between them. The owner had been declared insolvent and the curator of his estate recognised the builder's ${ }^{8}$ lien. Bristowe $\mathrm{J}$ explained the nature of the various expenses (necessary, useful and luxury). He went on to indicate ${ }^{9}$ that, even if a contract between the parties exists, the creditor should claim necessary and useful expenses on the basis of enrichment and luxury expenses on the basis of the contract. Shortly after making this statement the judge stated, obiter, ${ }^{10}$ that where there is an agreement between the creditor and the owner (debtor), all expenses agreed upon in the contract can be claimed by the creditor by means of this contractual lien. ${ }^{11}$

United Building Society v Smookler's Trustees and Golombick's Trustee 1906 TS 623. See Wiese 2017 LitNet Regte 304-321. Who was declared insolvent in the interim and was represented by the curator of his insolvent estate.

$9 \quad$ United Building Society v Smookler's Trustees and Golombick's Trustee 1906 TS 623 628. "Liens for voluptuariae impensae are not (so far as we have been able to discover) mentioned in terms; but frequent references occur to liens which creditors are said to possess who have incurred expenses on the property of their debtors, that is, liens for expenses incurred under contract with the owner of the property. So far as the expenses covered by these liens are necessariae or utiles it was not necessary to invent a new species of lien to denote them, for salvage and improvement liens would have been suffcient. But so far as they include voluptuariae impensae, or at all events expenses which are not shown to be either necessariae or utiles, it was necessary to refer them to some other principle than the maintenance or increase of market value. And the only other ground on which they can possibly be based is contract. It is easy, therefore, to see how the liens arising in cases of contract may have come to be treated as a class by themselves, although it was only really necessary to rely on contract for the proportion of the expenses (if any) which were not necessariae or utiles." The statement concerning a contractual lien (contractual lien) was made obiter since the judge found that the builder had an enrichment lien. United Building Society v Smookler's Trustees and Golombick's Trustee 1906 TS 623 628. "Now the debtor and creditor liens extend to all the expenses which the person who claims the lien has incurred upon the property under the contract, express or implied, which he made with the owner (Matthaeus, de Auctionibus, 1, 20, 18; Zupthen, Nederlandsch Practijk, sub voce Retentie, p. 547; Wassenaar, Practijk Judicieel, 1, 22, 76; Van Leeuwen, Commentaries, 4, 40, 2). But on the other hand such liens (or, to speak more exactly, such liens so far as they cover expenses which are not shown to be either necessariae or utiles), as they spring from the soil of the contract, so they are confined within the limits of contractual privity." 
In Brooklyn House Furnishers (Pty) Ltd $v$ Knoetze and Sons ${ }^{12}$ Botha JA ${ }^{13}$ stated obiter ${ }^{14}$ that when an owner has a contract with the lienholder and claims the thing from the lienholder by means of the rei vindicatio, the lien applies in respect of all agreed expenses, whether they are necessary, useful or luxuries. The creditor can withhold the thing until he has been compensated in full for the agreed expenses.

In Goudini Chrome (Pty) Ltd v MCC Contracts (Pty) Ltd ${ }^{15}$ Nienaber JA ${ }^{16}$ indicated obiter ${ }^{17}$ that a contractual lien applies against the other contracting party for all expenses as determined in the agreement.

In my opinion it is correct to say that a lien which is based on a contract between the creditor and the owner (debtor) vests in respect of the full contract price, irrespective of whether the expenses are necessary, useful or for luxuries. In these circumstances there can be no question of liability for enrichment, since the contract serves as the causa for the patrimonial transfer and there can therefore be no question of unjustified enrichment. Two liens could never exist over the same thing, as Bristowe $\mathrm{J}^{18}$ contends in United Building Society $v$ Smookler's Trustees and Golombick's Trustee: $:^{19}$ if there is a contract between the creditor and the owner (debtor), the creditor (lienholder) has a lien for the contract price; if there is no contract between them, the creditor (lienholder) has a lien for the amount of the enrichment. There is therefore only one lien in question, depending on whether or not a contract exists between the parties.

In the following paragraphs I shall discuss the question regarding the existence of a lien.

\section{Existence of a lien}

In principle, two liens could not exist over the same thing. If there is a contract between the creditor and the owner (debtor), the creditor

\footnotetext{
12 Brooklyn House Furnishers (Pty) Ltd v Knoetze and Sons 19703 SA 264 (A).

13 Brooklyn House Furnishers (Pty) Ltd v Knoetze and Sons 19703 SA 264 (A) 270H271B.

14 This statement was made obiter since the owner in this judgment did not have an agreement with the lienholder.

15 Goudini Chrome (Pty) Ltd v MCC Contracts (Pty) Ltd 19931 SA 77 (A).

16 Goudini Chrome (Pty) Ltd v MCC Contracts (Pty) Ltd 19931 SA 77 (A) 85G.

17 This statement was made obiter since the respondent in this matter had ceded all his rights to the bank and was consequently not able to vest a lien.

18 United Building Society v Smookler's Trustees and Golombick's Trustee 1906 TS 623628.

$19 \quad$ United Building Society v Smookler's Trustees and Golombick's Trustee 1906 TS 623.
} 
(lienholder) has a lien for the contract price; if there is no contract between them, the creditor (lienholder) has a lien for the enrichment amount. There is only one lien in question, depending on whether a contract exists between the parties. With reference to a factual scenario, I shall now distinguish between the following:

a) the creditor has a contract with a non-owner (the debtor), and

b) the creditor has a contract with the owner (the debtor).

\subsection{Creditor has a contract with non-owner}

Factual scenario: $X$ is the owner of a truck. The truck was damaged in an accident after which $X$ took it to $Y$ for repairs. $Y$ did not have the capacity to repair the truck and took it, without $X$ 's permission, to $Z$ for repairs. $X$ never instructed $Z$ to repair the truck. $Y$ and $Z$ agreed that $Z$ would repair the truck for R180 000 .

In this instance the agreement is between the creditor (Z) and a non-owner $(\mathrm{Y})$.

To establish the existence of a lien if there is an agreement with the nonowner, it must be determined which party claims the thing from the creditor, the owner or the other contract party?

\subsubsection{Rei vindicatio}

If the owner $(\mathrm{X})$ demands the return of his thing (the truck) with the rei vindicatio the creditor $(Z)$ can rely on a lien as a defence against the owner's rei vindicatio only if the owner has a duty to perform. The owner $(X)$ can be obliged to perform only if there is an obligation which compels him to do so: in the absence of a contract between the owner $(X)$ and the creditor $(Z)$, the creditor's legal claim could arise from enrichment. The amount the creditor (Z) could claim would be the amount by which the owner $(X)$ was enriched. Provided that all other requirements are met (e.g. the creditor is in control of the thing) the creditor (Z) can rely on an enrichment lien against the owner $(\mathrm{X})$.

\subsubsection{Exceptio non adimpleti contractus}

If the other contracting party (non-owner, in other words $Y$ in this example) claims the thing with a personal action arising from the contract, the creditor (Z) cannot rely on a lien. A lien applies as a defence against the rei vindication only. The creditor (Z) can rely only on the exceptio non adimpleti 
contractus, ${ }^{20}$ which is a contractual defence, or an exception in a contract action involving mutual duties or obligations, to the effect that the plaintiff may not sue if the plaintiff's own obligations have not been performed. No lien is vested in favour of the creditor $(Z)$ for its contractual claim against the debtor $(\mathrm{Y})$.

\subsection{Creditor has contract with the owner (debtor)}

Factual scenario: $X$ is the owner of a truck. The truck was damaged in an accident after which the owner took it to $Z$ for repairs. The parties agreed that $Z$ would repair the truck for $R 180000$.

If the owner of the truck $(X)$ uses the rei vindicatio to demand the return of the truck from the creditor $(Z)$ before he pays the creditor $(Z)$, the latter can rely on a contractual lien as a defence against the rei vindicato. The owner (X) has a duty to perform in terms of the agreement with $\mathrm{Z}$ and the creditor's legal claim is for the full contract price. The extent of the legal claim secured by the lien is determined by the contract - in other words the creditor $(Z)$ may retain the truck until the owner $(X)$ pays the agreed amount, R180 000.

The origin of the legal claim for which the lien serves as security determines the expenses for which a lienholder can vest his lien.

In the case of an enrichment lien, the lien can vest only for useful and necessary expenses. The extent of the lien is determined by enrichment and the lienholder can retain the thing until the owner has paid the enrichment amount.

20 In Smith $v$ Van den Heever 20113 SA 140 (SCA) paras 14 and 15, Harms, JA explains the legal operation of the exceptio non adimpleti contractus as follow: "As mentioned, Mr Smith's main defence is the exceptio non adimpleti contractus. The principles of this defence are well established and a detailed restatement is not required. As stated in the title 'Contract' in 5 (1) LAWSA 2 ed para 210, in the case of reciprocal contracts, one party undertakes to perform specifically in exchange for a particular counter performance by the other. In such cases, the principle of reciprocity applies: the first party is not entitled to demand counter performance from the other party unless the first party has him or herself performed or is prepared to perform, as the case may be. [15] In Motor Racing Enterprises, [1996 (4) SA 950 (A)] the court laid stress on the following relevant principles: First, the exceptio presupposes the existence of mutual obligations which are intended to be performed reciprocally, and that the parties' intention is to be sought primarily in the terms of their agreement. Second, interdependent promises are prima facie reciprocal. Third, the exceptio is often a temporary defence raised in order to compel the other contracting party to perform unfulfilled obligation(s) but only if defective performance of an obligatio faciendi can still be remedied. It is otherwise a complete defence. Fourth, the applicability of the exceptio is (subject to the de minimis principle) not dependent on the degree of non-performance." 
Contractual liens serve to secure the contractual legal claim and the amount is specified in the contract. Where the contract has been concluded with the owner, the contractual lien vests for all expenses which have been agreed upon - in other words, to ensure the contract price. Thus, a lien which is based on a contract between the creditor and the owner (debtor) vests in respect of the full contract price, irrespective of whether the expenses are necessary, useful or luxuries. In these circumstances there can be no question of liability for enrichment, since the contract serves as the causa for the patrimonial transfer and consequently there can be no question of unjustified enrichment.

I shall now consider the third-party or real operation of a lien.

\section{Real operation (third-party action)}

The next question that arises is against whom a lien may be applied. When referring to third-party (real) action it is firstly necessary to determine whether a lien does exist and, once it has been established that a lien is operating in a given situation, to determine against whom the lien can be maintained. Third-party action refers to the latter situation.

It is necessary to distinguish between the following two cases:

a) the "third-party action" of the contract between the creditor and the debtor against the owner in consequence of the enrichment principle;

b) the "third-party action" of the creditor's lien against persons other than the owner.

Only once it has been established that a lien exists against the owner (whether it takes the form of an enrichment lien or a contractual lien) does the question arise against whom it can be maintained. Because a lien is a defence against the owner's rei vindicatio, it is necessary to establish against which other persons (third parties) that lien can also be enforced.

It is self-evident that it can be enforced against the curator of the owner's insolvent estate because the former is in the place of the latter. In principle this will also apply to the owner's (debtor's) successors in title. Should the owner whose thing is subject to the creditor's lien sell the thing to a third party (successor in title), the latter will receive ownership of the thing subject to the creditor's lien. 
Other people who could possibly lay claim to the thing are other creditors of the owner and specifically real claimants to the thing. I shall now examine case law to determine what the lienholder's legal position is in respect of the above-mentioned persons.

In United Building Society $v$ Smookler's Trustees and Golombick's Trustee, ${ }^{21}$ as indicated above, the builder had a lien against the owner of the land in terms of an agreement between them. The owner had been declared insolvent and the curator of his estate recognised the builder's lien. A building society (United Building Society) had a mortgage over the insolvent owner's property and contended that their mortgage should enjoy preference over the builder's lien. On the facts, we are dealing with a contractual lien here. Had it not been for the owner's insolvency, the lien would have succeeded against the owner. The finding of the court, however, was that this was an enrichment lien. ${ }^{22}$ The relevant question here is whether this lien should receive preference ${ }^{23}$ over the real claims of other creditors (United Building Society). The judgment therefore turns on the third party operation of a lien. Bristowe $\mathrm{J}^{24}$ translated Voet (20.2.28) as follows:

$[T]$ he right of retention for repairs and improvements is available not only against creditors of the owners of the thing improved, but also against the owners themselves; so that they are neither liable to restore them to the owner nor to the curator bonis of a bankrupt debtor unless they have been fully satisfied in what is due to them for the labour or melioration.

Although Voet sets out the legal position clearly here, the judge is of the opinion that Voet's statement is somewhat vague. He concludes (like the legal representative of United Building Society - the plaintiff) that Voet is referring here only to concurrent creditors. It would appear from the full text of this passage in Voet ${ }^{25}$ that there is no obscurity. This specific passage is

United Building Society v Smookler's Trustees and Golombick's Trustee 1906 TS 623. United Building Society v Smookler's Trustees and Golombick's Trustee 1906 TS 623633.

23 See 5 below for a discussion of preference of a lien.

$24 \quad$ United Building Society $v$ Smookler's Trustees and Golombick's Trustee 1906 TS 623 628-629.

25 Gane Selective Voet 542-544. "It is however not to be denied that both by Roman law and also by our customs a right of retention has been bestowed both on the possessor of things movable and immovable, and in various wise on craftsmen who work on things movable, when they have repaired and improved them at their own cost and with their own labour, and still hold them. This is not only against the rest of the creditors of him who is the owner of the things improved, but also against the very owner of the thing. Such persons are therefore not held liable to hand back such things either to the owner or to the curator of the goods of an embarrassed debtor 
the last paragraph of Voet's discussion of the tacit hypothecs ${ }^{26}$ that are due to persons who advance money for the repair of buildings. Voet concludes this section by stating emphatically that according to Roman law and the custom in Holland the liens of occupiers and labourers apply against the owner, his creditors (who may, for example, wish to attach the thing) and his curator in the case of insolvency. This view was later confirmed in Spurrier $v$ CoxwelR7 and is regarded as correct.

In their discussion of United Building Society $v$ Smookler's Trustees and Golombick's Trustee ${ }^{28}$ Eiselen and Pienaar ${ }^{29}$ refer to other authors ${ }^{30}$ who are also of the opinion that an enrichment lien should enjoy preference over a registered mortgage. According to Eiselen and Pienaar one of the consequences of United Building Society $v$ Smookler's Trustees and Golombick's Trustee $^{31}$ is the erroneous view that an enrichment lien is an exception to the qui prior est tempore potior est jure principle. The authors indicate that this erroneous view was corrected in the decision in Lubbe $v$ Volkskas Bpk. ${ }^{32}$

In Lubbe $v$ Volkskas Bpk ${ }^{33}$ the appellant (Lubbe) had an agreement with the owner of a piece of land to sow wheat on that land. After Lubbe sowed his wheat he was informed that the land would be sold by the bank, as mortgagee, to cover the owner's unpaid debts. Lubbe approached the court for an urgent order declaring that he had a lien over the land. The court dismissed Lubbe's ex parte application. All subsequent appeals against the court a quo's finding were also dismissed. Smuts JP ${ }^{34}$ made no finding on

unless full satisfaction has been given them as to what their rights allow them to recover under the head of labour or that of improvements."

It can be presumed that Voet viewed all hypothecs as real. I am of the opinion that a lien in South African law is not a subjective right (either a real right or a personal right), but a legally recognised retention capacity to which the lienholder has an extrajudicial claim and a mere defence against the owner's rei vindicatio (or the claim to the thing of another real claimant). See Brits Real Security Law 487-488; Sonnekus and Neels Sakereg Vonnisbundel 771; Sonnekus Ongegronde Verryking 219-220, Sonnekus 1991 TSAR 462-482; and Wiese 2017 LitNet Regte 304-321. United Building Society v Smookler's Trustees and Golombick's Trustee 1906 TS 623. Eiselen and Pienaar Unjustified Enrichment 268. The authors refer to Scott "Lien" 133; Mars et al Law of Insolvency 384-385; Delport and Olivier Sakereg Vonnisbundel 495; Scott and Scott Mortgage and Pledge 97; and Van der Merwe Sakereg 724. All of these authors refer to the United Building Society $v$ Smookler decision as authority. United Building Society v Smookler's Trustees and Golombick's Trustee 1906 TS 623.

$32 \quad$ Lubbe $v$ Volkskas Bpk 19923 SA 868 (A).

$33 \quad$ Lubbe $v$ Volkskas Bpk 19923 SA 868 (A).

$34 \quad$ Lubbe $v$ Volkskas Bpk 19911 SA 398 (O) 409E-F. 
the nature of a lien but it seems as if the court accepted that a lien was a real right because it indicated, by way of obiter dictum, that the prior in tempore rule applies to liens. ${ }^{35}$ It was mentioned that the mortgage had vested before the lien and would possibly enjoy preference over the lien in consequence of the prior in tempore rule. The court did not rule on the existence of a lien or on its enforceability. The judgment merely made obiter observations on the third-party operation of a lien.

At first glance it would appear that the principle is related to the order of preference of liens. I am of the opinion, however, that it is applicable to the third-party action of liens. The question therefore is against which persons other than the owner of the thing the lien can be enforced.

It should be borne in mind that Lubbe $v$ Volkskas Bpk was first heard before a single judge of the Orange Free State Provincial Division, after which Lubbe appealed to the full bench of the same court ${ }^{36}$ and then to the appeal court. The appeal before the full bench of the Orange Free State Provincial Division concerned costs for the urgent application before the single judge. In the appeal to the full bench the single judge's decision was confirmed and in the appeal to the appeal court ${ }^{37}$ the decision of the full bench was confirmed. In the decision of the full bench ${ }^{38}$ of the Orange Free State Provincial Division the court ${ }^{39}$ went into the question whether a bona fide possessor who had made improvements on the land of the owner after a mortgage had already vested on the land enjoyed preference over the mortgagee. ${ }^{40}$ The court ${ }^{41}$ emphasised the fact that the owner in this case was not insolvent at the time of the inquiry before the single judge and that the principles applicable in insolvency do not apply here. The court made an obiter finding that the prior in tempore rule applied and the lien was therefore subordinate to the mortgage - and that the lien therefore did not have third party action against a prior mortgagee. The judge went on to say that there would be harmful consequences for investors in fixed property if a lessee could enter into a lease after the mortgage had been registered and thereby create a condition where the mortgagee who wished to sell the encumbered property would have to do this subject to the lessee's lien. ${ }^{42}$

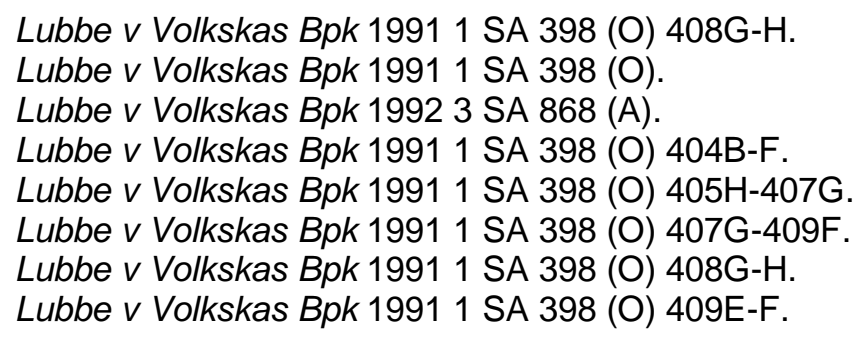


According to Sonnekus, ${ }^{43}$ the mortgagee is enriched by the improvements made, but, like the court, he says that the bona fide lessee or occupier who is unable to enforce his lien against the mortgagee still has an enrichment claim against the whole world and a claim for damages against the lessor who has been guilty of breach of contract. Sonnekus ${ }^{44}$ criticises the application of the prior in tempore rule in the case of liens since this maxim is applicable only to real rights and, in his opinion, a lien does not qualify as a real right.

If one examines the decision in Lubbe $v$ Volkskas $B p k^{45}$ more closely, it becomes evident that the point with regard to the prior in tempore rule was made obiter. The court stated that at the time of the application there was no lien in operation. The court merely said that if there had been a lien, the prior in tempore rule would probably apply. It is important to note that the owner (debtor) in the Lubbe judgment was not insolvent at the time when the creditor applied for a declaratory order confirming that he had a lien. If the owner had been insolvent, the provisions of the Insolvency Act 24 of 1936 would have applied.

Even before the Lubbe decision, Hutchison et $a^{46}$ referred to Voet 20.4.19 and United Building Society $v$ Smookler as authority for the statement that a lien applies against a registered mortgage, even if the mortgage was registered before the lien - and thus has third-party action against the prior mortgagee.

Van der Merwe ${ }^{47}$ is of the opinion that a lien is enforceable against other real claimants:

Aangesien die besteding van geld of arbeid deur die retentor tot gevolg het dat die waarde van die saak verhoog word of ten minste verhinder dat die waarde daarvan afneem, werk hierdie reëling nie onbillik in die praktyk nie. ${ }^{48}$

According to Van der Merwe it is equitable that a lienholder's lien also applies against other real claimants. Van der Merwe's statement is not based on the application of the prior in tempore rule but purely on equity.

\footnotetext{
$43 \quad$ Sonnekus Ongegronde Verryking 225.

$44 \quad$ Sonnekus Ongegronde Verryking 225.

$45 \quad$ Lubbe $v$ Volkskas Bpk 19923 SA 868 (A).

$46 \quad$ Scott and Scott Mortgage and Pledge 344.

$47 \quad$ Van der Merwe Sakereg 724 fn 930.

48 Translation: Since the expenditure of money or labour by the retentor increases the value of the thing or at least prevents it from declining, this arrangement is not unfair in practice.
} 
Sonnekus ${ }^{49}$ also calls into question the application of the prior in tempore rule to liens. He states that the prior in tempore rule is applied only where there is a concurrence of various real rights. As indicated above, Sonnekus is of the opinion that a lien is not a real right and consequently the prior in tempore rule is not applicable. With the concurrence of creditors in particular circumstances the mortgagee is indeed enriched thanks to inputs by the custodian of the thing. Due to the care taken of the mortgaged property, the mortgagee would have no need, in respect of the shortfall that would otherwise have arisen from the meagre proceeds from the neglected mortgaged property, to rely on a concurrent claim in respect of the free residue. A mortgagee with an unsecured claim against the free residue of the owner's insolvent estate would scarcely count on full recovery of his claim and would expose himself to a compulsory contribution.

Because of my support for Sonnekus's viewpoint that liens are not real rights, I share his opinion that the prior in tempore rule is not applicable in determining whether a lienholder's lien can be enforced against a mortgagee with an earlier or later right to the thing. Although their explanations differ, both Van der Merwe and Sonnekus are of the opinion that this third-party action is based on fairness (billikheid). The views of these authors do not differ in any essential respect. Van der Merwe is of the opinion that a lien trumps the prior in tempore rule on the grounds of fairness. Sonnekus contends that where there is a concurrence of creditors the mortgagee could undoubtedly have been enriched by the creditor's (lienholder's) actions and that the lien should therefore be applicable against the mortgagee who has a mortgage over the land.

As regards the position of a lienholder in the case where the owner (debtor) is insolvent, Voet has stated emphatically that the lien is applicable against the owner, his curator and other creditors. United Building Society $v$ Smookler's Trustees and Golombick's Trustee ${ }^{50}$ to some extent confirmed Voet's view. In Spurrier v Coxwel/ ${ }^{15}$ Kotze $\mathrm{J}^{52}$ referred to Voet in this regard:

The rule of our law is that a person who has bestowed work and labour on the thing of another whether for its preservation, improvement or repair, has a jus retentionis of the thing itself, and is not obliged to restore it to its owner, nor, as Voet tells us, to a curator bonis of a bankrupt debtor, unless he has first

$49 \quad$ Sonnekus Ongegronde Verryking 224.

50 United Building Society v Smookler's Trustees and Golombick's Trustee 1906 TS 623.

$51 \quad$ Spurrier v Coxwell 1914 CPD 83.

52 Spurrier v Coxwell 1914 CPD 8388. 
been paid what is due for the work done upon or improvement of the thing (20.2.28 in fine).

Pienaar and Steven ${ }^{53}$ provide the following explanation of the way a lien operates:

A fundamental issue is whether a lien is a real right, or in other words whether it can be enforced against the owner of the property, his successors and his creditors.

The authors indicate that enrichment liens are real rights and contractual liens are personal rights. On this basis they give the following example:

In principle, if A is retaining B's property pursuant to a contractual claim, A's debtor and creditor lien is only enforceable against $B$. That, however, is not entirely accurate. A debtor and creditor lien can be enforced against B's universal successors.

In essence these authors are placing liens of all kinds on an equal footing (regarding the universal successors) by stating that not only enrichment liens but also contractual liens are enforceable against the owner's universal successors in title. They refer to the decision in Levy $v$ Tyler $^{54}$ in which it was decided that contractual liens were also enforceable against B's successors who were aware of the lien. This argument may be based on the doctrine of notice.

The only clear indications in our law regarding the third-party operation of liens are to be found in United Building Society $v$ Smookler's Trustees and Golombick's Trustee ${ }^{55}$ : a lien has third-party operation against a secured creditor (mortgagee) of the owner (debtor). ${ }^{56}$ Since the observations in respect of the prior in tempore principle were made obiter in Lubbe $v$ Volkskas $B p k{ }^{57}$ they do not serve as authority for the statement that a lien is not enforceable against a prior mortgagee.

The biggest cause of uncertainty regarding the third-party action of a lien is related to the present classification of liens into real rights and personal rights. This uncertainty has arisen as a result of a failure to distinguish between the existence of a lien and its third-party action. If it is accepted

\footnotetext{
$53 \quad$ Pienaar and Steven "Rights in Security" 785.

$54 \quad$ Levy $v$ Tyler 1933 CPD 377.

$55 \quad$ United Building Society $v$ Smookler's Trustees and Golombick's Trustee 1906 TS 623.

$56 \quad$ This approach can be widely interpreted, since United Building Society $v$ Smookler's Trustees and Golombick's Trustee 1906 TS 623.deals with a contractual lien and the court found that this was an enrichment lien.

57 Lubbe v Volkskas Bpk 19923 SA 868 (A).
} 
that a lien is a legally recognised capacity to withhold to ensure that a legal claim will be met (and not a real or personal right), and it is a defence against the owner's rei vindicatio, the origin of the legal claim will have no effect on the nature of the lien. The current categorisation of liens is at most an indication of the different origins of the legal claim to which the lien is accessory. For the purposes of the third-party action of liens, no distinction should therefore be drawn between enrichment liens and contractual liens.

\section{Preference}

Preference arises when it is necessary to determine whether one creditor has a preferential legal claim to a specific asset in a debtor's estate. If it has been established that a lien has vested, the order of preference of such liens must be determined. This question was addressed for the first time in 1906 in United Building Society $v$ Smookler's Trustees and Golombick's Trustee. ${ }^{58}$ The provisions of the Insolvency Act 24 of 1936 currently give preference to liens. United Building Society $v$ Smookler's Trustees and Golombick's Trustee was decided before the coming into operation of the Insolvency Act. I shall briefly discuss the decision to illustrate some problems with the judge's view of the legal position of a lienholder before the enactment of the Insolvency Act.

In United Building Society v Smookler's Trustees and Golombick's Trustee ${ }^{59}$ the judge ${ }^{60}$ based his finding in respect of the order of preference of liens on the assumption that an enrichment lien is a real right and a contractual lien is not. Although the lien in question here was a contractual lien ${ }^{61}$ in my opinion, the judge found that it was an enrichment lien. He explained that the lien, if it qualified as a real right, would rank before the mortgage in terms of the chronological sequence, because the mortgage vested after the lien.

United Building Society v Smookler's Trustees and Golombick's Trustee 1906 TS 623.

United Building Society v Smookler's Trustees and Golombick's Trustee 1906 TS 623.

$60 \quad$ United Building Society $v$ Smookler's Trustees and Golombick's Trustee 1906 TS 623 631-632. "And if this lien [contractual lien] were really radically distinct in its entirety from a lien for utiles impensae, there can be no doubt that this case would have to be decided adversely to the builder, unless it could be held that the jus retentionis for all expenses is a real right. In that case it would take its natural place in chronological sequence, and (subject to question of notice) would come in front of the building society's mortgage, assuming the latter be (as it appears to be) subsequent in point of time. But if it is not a real right, then (subject to considerations of notice) the mortgage, being registered and being therefore a real right, would in our opinion come first."

61 There was an agreement between Smookler (the owner) and Golombick (the builder) in terms of which the builder erected the buildings. 
This assumption is also erroneous, however - the mortgage was registered on 12 December 1904 and the builder completed the buildings only in February 1905, after which the owner failed to meet his legal claim. The lien therefore vested after the mortgage. The court did not refer to and discuss the maxim qui prior est tempore potior est jure directly, but through references to sections that deal with it. ${ }^{62}$ The court accordingly decided that Golombick's lien enjoyed preference over the building society's mortgage.

I shall now turn to the provisions of the Insolvency Act 24 of 1936.

Section 2 of the Insolvency Act defines preference as follows:

'preference' in relation to any claim against an insolvent estate, means the right to payment of that claim out of the assets of the estate in preference to other claims; and 'preferent' has a corresponding meaning

Section 2 of the Insolvency Act 24 of 1936 defines a lien as a preferent right:

'security' in relation to the claim of a creditor of an insolvent estate, means property of that estate over which the creditor has a preferent right by virtue of any special mortgage, landlord's legal hypothec, pledge or right of retention;

Note that the Insolvency Act does not distinguish between different types of liens, but simply refers to a lien.

Section 47 expressly determines that a lien enjoys preference over the claims of other creditors:

If a creditor of an insolvent estate who is in possession of any property belonging to that estate, to which he has a right of retention or over which he has a landlord's legal hypothec, delivers that property to the trustee of that estate, at the latter's request, he shall not thereby lose the security afforded him by his right of retention or lose his legal hypothec, if, when delivering the property, he notifies the trustee in writing of his rights and in due course proves his claim against the estate: Provided, that a right to retain any book or document of account which belongs to the insolvent estate or relates to the insolvent's affairs shall not afford any security or preference in connection with any claim against the estate.

Section 83(11) provides that a lienholder cannot refuse to deliver the thing over which he has a lien to the trustee of the insolvent estate if the latter compensates him for the outstanding legal claim:

If a creditor has valued his security when proving his claim, the trustee, if authorized by the creditors, may, unless the creditor has realized his security

62 United Building Society v Smookler's Trustees and Golombick's Trustee 1906 TS 623 629, 631-632. 
in terms of subsection (2) ${ }^{63}$ or (3), ${ }^{64}$ within three months as from the date of his appointment or as from the date of the proof of the claim (whichever is the later) take over the property (whether movable or immovable) which constitutes the security at the value placed thereon by the creditor when his claim was proved: Provided that if two or more creditors have a pledge or special mortgage of the same property, a creditor who has valued his security shall be deemed to have valued, and the trustee shall be entitled to take over, only the preferent rights of the creditor in respect of the property, and not the property itself. If the trustee does not, within that period, take over the said property or security he shall realize it for the benefit of all creditors whose claims are secured thereby, according to their respective rights.

A trustee can therefore demand the thing over which the lienholder has a lien only if he has satisfied the lienholder's legal claim against the insolvent estate.

In terms of the Insolvency Act a lien can therefore be enforced against the insolvent estate of an owner (debtor) and it gives the lienholder preference, in respect of the thing in question, above other creditors of the insolvent.

Pienaar and Steven ${ }^{65}$ refer to section 95(1) of the Insolvency Act 24 of 1936 and state the following:

By statute, the debtor and creditor lien is enforceable against B's [owner (debtor)] unsecured creditors. For this reason, Van der Merwe contends, contrary to the orthodox position, that the lien has some real effect. This is criticised by Scott on the basis that the relevant law is statutory. But the criticism seems groundless. The lien must be juridically classified in terms of the law which governs it, be that statute law or otherwise.

In this section the authors provide that a contractual lien is enforceable against the unsecured creditors of the owner (debtor) and that it therefore enjoys a measure of real effect. It is clear to me from the above discussion that this is undoubtedly the position as prescribed by the Insolvency Act 24

63 "If such property consists of a marketable security, a bill of exchange or a financial instrument as defined in section 1 of the Financial Markets Control Act, 1989 (Act No. 55 of 1989), the creditor may, after giving the notice mentioned in subsection (1) and before the second meeting of creditors, realize the property in the manner and on the conditions mentioned in subsection (8)."

64 "If such property does not consist of a marketable security or a bill of exchange, the trustee may, within seven days as from the receipt of the notice mentioned in subsection (1) or within seven days as from the date which the certificate of appointment issued by the Master in terms of sub-section (1) of section eighteen or sub-section (2) of section fifty-six reached him, whichever be the later, take over the property from the creditor at a value agreed upon between the trustee and the creditor or at the full amount of the creditor's claim, and if the trustee does not so take over the property the creditor may, after the expiration of the said period but before the said meeting, realize the property in the manner and on the conditions mentioned in subsection (8)."

$65 \quad$ Pienaar and Steven "Rights in Security" 785. 
of 1936. It is important to say that the Insolvency Act does not distinguish between various types of liens. Section 95(1) of the Insolvency Act deals with the proceeds from the sale of a property which was subject to a mortgage, a landlord's hypothec, a pledge or a lien. This section reads as follows:

\begin{abstract}
The proceeds of any property which was subject to a special mortgage, landlord's legal hypothec, pledge or right of retention, after deduction therefrom of the costs mentioned in subsection (1) of section eighty-nine, shall be applied in satisfying the claims secured by the said property, in their order of preference, with interest thereon calculated in manner provided in subsection (2) of section one hundred and three from the date of sequestration to the date of payment, but subject to the provisions of subsection (4) of section ninety-six.
\end{abstract}

The preferent position ${ }^{66}$ of a lien upon the insolvency of the owner (debtor) is expressly regulated by the Insolvency Act 24 of 1936. A lien enjoys preference over other real claimants because the lienholder can retain control over the thing until the curator of the insolvent estate duly collects it, ${ }^{67}$ upon which the lienholder may not refuse to hand over the thing to the curator. $^{68}$ This position accords with Voet's statement (20.2.28) that the lien is enforceable against the owner, his curator and other creditors.

In Roux $v$ Van Rensburg ${ }^{69}$ the question was whether a lienholder can enforce his lien against the curator of the owner's (debtor's) insolvent estate. The appellants alleged that they had a lien over the land for improvements they had made. When the land had to be sold in execution the appellants refused prospective buyers access to the land and exercised their lien in this way. The respondents approached the court a quo for an urgent eviction order against the appellants. The court a quo granted the application, upon which the appellants lodged an appeal. It was decided on appeal that the curator of an insolvent estate may request the lienholder to deliver the thing over which he has a lien to the curator, against security. The court accepted, relying on United Building Society $v$ Smookler's Trustees and Golombick's Trustee ${ }^{70}$ Kommissaris van Binnelandse Inkomste v Anglo American (OFS) Housing Co Ltd ${ }^{71}$ and Brooklyn House Furnishers (Pty) Ltd $v$ Knoetze and

\footnotetext{
$66 \quad$ Section 2 of the Insolvency Act 24 of 1936.

67 Section 47 of the Insolvency Act.

68 Section 83(11) of the Insolvency Act.

69 Roux v Van Rensburg 19964 SA 271 (A).

70 United Building Society v Smookler's Trustees and Golombick's Trustee 1906 TS 623627.

71 Kommissaris van Binnelandse Inkomste v Anglo American (OFS) Housing Co Ltd 19603 SA 642 (A) 649E-650A.
} 
Sons ${ }^{72}$ that an enrichment lien is a real right. Although the precise facts in terms of which a lien vested are not clear from the decision, the judge stated that the issue was expenditure for useful and necessary improvements and that therefore it was an enrichment lien.

Howie $\mathrm{JA}^{73}$ explained that it might be detrimental for a lienholder to keep the thing under his control during an insolvency. In practice there may often be good reasons for the curator of the insolvent estate to take possession of encumbered immovable property before he sells it, as was the situation in the present case. The appellants' possession was detrimental to the sale of the property and consequently to other creditors. The judge further stated that it is not in the interests of legal certainty, successors in title or creditors if a lienholder with a real right over fixed property is able to delay the winding up of the estate indefinitely.

The court then referred to section 47 of the Insolvency Act 24 of 1936, which provides that, if a lienholder gives control over movable or immovable property of the insolvent estate on which he has a lien to the curator at the request of the curator, he does not lose the security the lien affords him if he notifies the curator in writing of his rights and in due course proves his claim against the estate. The section presupposes that the common law obligation of the lienholder to deliver possession of the property to the curator applies. The lienholder is protected if he responds to any request and gives the necessary notice of his rights. In the present case the respondents' application for an eviction order was a request to get control over the immovable property. The appellants refused to give control over the immovable property to the curator.

The court then referred to section 83(11) of the Insolvency Act 24 of 1936, which provides that the lienholder cannot refuse to deliver the thing if he has already been compensated by the curator. Howie JA therefore decided that the appellants should give up control of the farm.

\section{Summary}

A clear distinction is not always drawn between the existence of a lien and the consequences for third parties. Regarding the origin of liens, there are two clearly distinguishable cases: where the creditor has a contract with a non-owner and is therefore able to vest a lien against the owner of the thing

\footnotetext{
72 Brooklyn House Furnishers (Pty) Ltd v Knoetze and Sons 19703 SA 264 (A) 271BD. 
only on the grounds of unjustified enrichment (enrichment lien); or where the creditor has a contract with the owner (creditor) and the contract is the basis for the liability of the owner (debtor) (contractual lien).

In the case of enrichment liens, the lien serves to secure a legal claim for useful and necessary expenses, therefore to secure payment of the enrichment amount. A lien of this nature never covers expenditure on luxuries, since the legal claim which it serves to secure originated from enrichment, and expenditure on luxuries cannot be claimed with an enrichment action. In the case of a contractual lien which serves to secure a creditor's legal claim arising from a contract with the owner, the lien vests to secure the payment of the contract amount, that is to say the amount on which the parties agreed - and this could include luxury expenditure.

Since a lien is a defence against the owner's rei vindicatio, in principle it is enforceable against the owner. The question of the third-party action of a lien concerns parties other than the owner against whom the lien can be raised. In my view both enrichment liens and contractual liens can be enforced against the curator of the owner's insolvent estate as well as the owner's successors in title, since they take the owner's place. A lien can also be enforced against the creditors ${ }^{74}$ of the owner (debtor) and other real claimants. In Lubbe $v$ Volkskas Bpk ${ }^{75}$ the court decided obiter that the prior in tempore principle would apply in this case. In my opinion this was not the correct decision since a lien does not qualify as a subjective right.

The question of the preference enjoyed by liens arises upon the insolvency of the owner. In terms of sections 2, 47 and 83(11) of the Insolvency Act 24 of 1936, in the event of the insolvency of the owner (debtor) a lien enjoys preference over the claims of other creditors of the owner (debtor).

\section{Bibliography}

\section{Literature}

Brits Real Security Law

Brits R Real Security Law (Juta Cape Town 2016)

$74 \quad$ Wishing, for example, to attach the thing.

75 Lubbe $v$ Volkskas Bpk 19923 SA 868 (A). 
Delport and Olivier Sakereg Vonnisbundel

Delport HJ and Olivier NJJ Sakereg Vonnisbundel $2^{\text {nd }}$ ed (Juta Cape Town 1985)

Eiselen and Pienaar Unjustified Enrichment

Eiselen S and Pienaar G Unjustified Enrichment: A Casebook $4^{\text {th }}$ ed (LexisNexis Durban 2017)

Gane Selective Voet

Gane P The Selective Voet being the Commentary on the Pandects by Johannes Voet and the Supplement to that Work of Johannes Van der Linden vol 3 (Butterworths Durban 1956)

Mars et al Law of Insolvency

Mars WH et al The Law of Insolvency in South Africa $9^{\text {th }}$ ed (Juta Cape Town 2008)

Mostert and Pope Beginsels van die Sakereg

Mostert $\mathrm{H}$ and Pope A (eds) Die Beginsels van die Sakereg in Suid-Afrika (Oxford University Press Cape Town 2010)

Muller et al Law of Property

Muller $\mathrm{G}$ et al Silberberg and Schoeman The Law of Property $6^{\text {th }}$ ed (LexisNexis Durban 2019)

Pienaar and Steven "Rights in Security"

Pienaar G and Steven AJM "Rights in Security" in Zimmermann R, Visser

$\mathrm{D}$ and Reid K (eds) Mixed Legal Systems in Comparative Perspective: Property and Obligations in Scotland and South Africa (Juta Lansdowne 2004) 758-786

Scott "Law of Real and Personal Security"

Scott SJ "The Law of Real and Personal Security" in Scott TJ (ed) The Law of Commerce in South Africa (Oxford University Press Cape Town 2010) ch 7

Scott "Lien"

Scott TJ "Lien" in Joubert WA (ed) The Law of South Africa vol 15(2) $2^{\text {nd }}$ ed (LexisNexis Butterworths 2008)

Scott and Scott Mortgage and Pledge

Scott TJ and Scott SJ Wille's Principles of Mortgage and Pledge in South Africa $3^{\text {rd }}$ ed (Juta Cape Town 1987) 
Sonnekus 1991 TSAR

Sonnekus JC "Retensieregte - Nuwe Rigting of Misverstand par Excellence?" 1991 TSAR 462-482

Sonnekus Ongegronde Verryking

Sonnekus JC Ongegronde Verryking in die Suid-Afrikaanse Reg (LexisNexis Butterworths Durban 2007)

Sonnekus and Neels Sakereg Vonnisbundel

Sonnekus JC and Neels JL Sakereg Vonnisbundel $2^{\text {nd }}$ ed (LexisNexis Butterworths Durban 1994)

Van der Merwe Sakereg

Van der Merwe CG Sakereg $2^{\text {nd }}$ ed (LexisNexis Butterworths Durban 1989)

Wiese 2017 LitNet Regte

Wiese M "Vonnisbespreking: Die (Ongegronde) Grondslag vir die Klassifisering en Werking van Retensieregte in die Suid-Afrikaanse Reg: United Building Society v Smookler's Trustees and Golombicks Trustees 1906 TS 623" 2017 LitNet Regte 304-321

\section{Case law}

Brooklyn House Furnishers (Pty) Ltd v Knoetze and Sons 19703 SA 264 (A)

D Glaser and Sons (Pty) Ltd v The Master 19794 SA 780 (C)

Goudini Chrome (Pty) Ltd v MCC Contracts (Pty) Ltd 19931 SA 77 (A)

Kommissaris van Binnelandse Inkomste $v$ Anglo American (OFS) Housing Co Ltd 19603 SA 642 (A)

Levy v Tyler 1933 CPD 377

Lubbe v Volkskas Bpk 19911 SA 398 (O)

Lubbe v Volkskas Bpk 19923 SA 868 (A)

Roux v Van Rensburg 19964 SA 271 (A)

Smith $v$ Van den Heever 20113 SA 140 (SCA)

Spurrier v Coxwell 1914 CPD 83 
Syfrets Participation Bond Managers Ltd $v$ Estate and Co-op Wine Distributors (Pty) Ltd 19891 SA 106 (W)

United Building Society v Smookler's Trustees and Golombick's Trustee 1906 TS 623

\section{Legislation}

Insolvency Act 24 of 1936

\section{List of Abbreviations}

TSAR

Tydskrif vir die Suid-Afrikaanse Reg 